\title{
Hyperlocal Journalism and PR: Diversity in Roles and Interactions
}

\author{
Lottie Jangdal*, Asta Cepaite-Nilsson**, Elisabeth Stúr*
}

*Mid Sweden University, Sweden

**Lund University, Sweden

Abstract

\begin{abstract}
Hyperlocal media has repeatedly been framed as a potential saviour of local journalism, but the democratic and civic role that often is ascribed to hyperlocals is not obvious or uncomplicated. The hyperlocals' vulnerable economic situation makes them dependent on free content, for example material produced by local councils or organizations. This paper investigates the role of hyperlocal media entrepreneurs and their interaction with local councils and other stakeholders. We examine how the hyperlocal media entrepreneurs supply their communities with news in places of a media void, and how they perceive their role in their communities. Findings from this qualitative study show that the media entrepreneurs view their news production as an important part of the local community. They provide a forum for debate and information for citizens, local governments and organizations. Their service also includes a channel for local events relevant for the community. The interactions with the local governments vary, as well as the hyperlocal entrepreneurs' evaluation of how the information provided by the councils can or should be handled. The relation between hyperlocal media entrepreneurs and local governments is a complex process, including both interrelated and contradictory goals.
\end{abstract}

Keywords: hyperlocal news, media entrepreneurs, PR, community, local governments

Submitted: 20th March 2018

Accepted: 20th December 2018

\section{Introduction}

During the last decade, there have been huge changes in the local media market all over the world. One main factor in the development is how local media companies have re-oriented their way of working, for instance moving local reporters to head offices and at the same time shutting down local newsrooms. One consequence of this change is that local councils on the countryside have been left without any apparent media platform for communication with their citizens. What is called "media blank spots" have appeared (Cook, Geels, \& Bakker, 2016). Issues of relevance to citizens in their everyday lives - about their local hospitals and schools, businesses and courts - are not being addressed. Local decision makers are not being questioned or held to account (Barnett, 2009). As a result of this development local media entrepreneurs have started their own media news agencies in order to fill the gap of information (Pickard \& Stearns, 2011). Sweden is one example of this development. During the past years, an amount of hyperlocals has been established on the countryside, with the aim to fill the media void by covering the local news (Leckner, Tenor, \& Nygren, 2017). The term hyperlocal describes independent online local news sites. Radcliffe (2012, p. 6) defines hyperlocals as 'online news or content services pertaining to a town, village, single postcode or other small, geographically defined community'. The most common topic covered by hyperlocals relate to community activities, local councils and the services they provide.

Independent journalism is traditionally seen as being a crucial factor for democratic civil society, including the role of citizens as media critics (Holt \& von Krogh, 2010). The hyperlocal media has been framed as a 
potential saviour of local journalism. Radcliffe (2015) suggests that hyperlocal media play an important democratic role in helping people to root themselves in the local community and provide the geographic location with meaning. While much research about hyperlocal news offers insights into its value, and limitations, little has been done to examine the more innovative, less traditional roles that hyperlocal publishers play (Harte, Williams, \& Turner, 2017). Williams, Harte and Turner (2015) and Barnett and Townend (2015) argue that hyperlocals give voice to local communities, contribute to the plurality of local media, cover community activities and topics related to local councils.

The democratic and civic role that often is ascribed to hyperlocals is not obvious or uncomplicated. The hyperlocals are driven by various motives of the publishers, which not necessarily have investigative reporting as their primary goal. Some of them may view the hyperlocal site as a mean to showcase the community by reporting on all the good things happening there. Hyperlocal publishers may include, as Radcliffe (2015) describes in the study for Nesta, entrepreneurial journalists, reporters deeply rooted in a community, community activists, concerned citizens or people with no journalistic background at all.

Compared with mainstream media, the hyperlocals have fewer resources to review local issues. But content production does cost. Most costly are those activities that require source-checking, research and investigation (Harte et al., 2016). The hyperlocals' vulnerable economic situation and the production conditions, which are largely characterized by one-man newsrooms, also make them, to a certain extent, dependent on free content or information that easily can be accessed, e.g. content produced by local councils or organizations. Collaboration between local councils and new established hyperlocal media entrepreneurs can, on several levels, be interpreted as a move towards more interweaving roles and practices. Diffuse professional roles and a mixture of editorial content and PR material have been discussed in a context of mainstream media. Researchers have been debating how the line between PR and journalism roles is continuously blurring, consequently making it difficult for citizens to identify the information source and perceive the content and the news journalism as trustworthy (Macnamara, 2016; Allern, 2002). Allern (2015) observes in a study how effective professional news sources use different journalistic formats and genres in their production of information subsidies for PR aims. In addition to the explanation that journalists are seeking faster and cheaper ways to produce the news, and therefore PR material is used to a higher degree, there is another reason why PR material is used or incorporated into the news content: PR material is, in some cases, not recognized as such because PR practitioners can be seen by journalists as trusted sources. Hyperlocal publishers may also face the same challenges in their content production. By local councils, interest groups and organizations they might be considered as an attractive and accessible forum for PR material, since the hyperlocal sites offer an information platform for a local community. Diversity in background of hyperlocal publishers in their publicist goals and experience make them exposed for PR professionals and consequently makes it difficult to manage and balance relationships with these professional communicators. While editorial independence is one of the important issues for hyperlocals (Harte et al., 2016), the publishers may not have enough experience, knowledge or resources for financing their publishing activities. In a study of hyperlocal publishers, Radcliffe (2015) found that some hyperlocals have a good relationship with local councils. Still, others are aware of potential risks in establishing close contacts with local governments or other organizations and ignore them as they consider that council communicators are just a source of PR material. 
Although more and more professional hyperlocal media are established on the Swedish and the international media market, it is continuously questioned whether and in which ways these entrepreneurs can replace or supplement traditional media coverage (Karlsson \& Holt, 2014; Wadbring \& Ödmark, 2016). It is also questionable how the hyperlocals perceive their role fulfilling civic function in the local community, and how the perception of their function impact interaction with local councils and organizations.

The object of this study is to investigate the role of hyperlocal media entrepreneurs and their interaction with local councils and other stakeholders in order to supply their communities with hyperlocal news in places of a media void. In this investigation, cases from the Swedish local media market are used as samples.

\section{Theoretical framework}

Over the last decade, the conditions for local news reporting on the countryside have altered considerably. As a consequence of a poorer local reporting - some Swedish communities experience heavily reduced news coverage and some communities in the countryside totally lack media representation. Both inhabitants and various stakeholders, such as local councils, have lost their channel of information. Firmstone and Coleman (2014) point out that the news media have changed from a model of regular face-to-face contact with local representatives and represented communities, as well as attendance at council meetings, to a reliance on press releases and an 'as and when necessary' approach to direct reporting on the democratic process. The perceived lack of news monitoring can be one of the reasons for local authorities to establish their own ways of communication with the community. A county council in Sweden, Västra Götaland (VGR), has recently started a news site, VGRfokus, a channel for regional council information, with communicator Erik Lagersten as the publisher and a number of council officials on the editorial team. This action was explained by the communicator: "If journalism does not report on county councils, how do our residents get insight into our operation? (...) Editorials in Västra Götaland have too little time and knowledge needed to report regularly about VGR" (Lagersten, 2017).

In the theoretical framework, we discuss the hyperlocal entrepreneurs' role and function in the new journalistic landscape as well as the ways journalism and PR get closer - and what implications these relationships might have for news journalism.

\section{Interdependence and networks of hyperlocal media entrepreneurs}

Democratic functions are not necessarily limited to traditional news media but can be fulfilled by social media and hyperlocal news platforms. Digital media are challenging the underlying, long-held principles of journalistic objectivity, which were once central to legacy media's methodology (Carson, Muller, Martin, \& Simons, 2016).

Hyperlocal media is characterized by limited topics or geographic coverage areas (Kurpius, Metzgar, \& Rowley, 2010). The growth of hyperlocal news websites with community orientation has attracted increased attention of researchers in the United Kingdom. A study of hyperlocal revenues in the United Kingdom and Europe calls the independent hyperlocal ecosystem a 'messy sector' (Cook et al., 2016), implying that there 
are numerous prototypes, variations on funding and sustainability deviances. There are interdependencies between people and partnerships in the local setting that are dynamic and imbalanced.

Harte, Turner and Williams (2016) describe hyperlocal media as contrasting to the ongoing narratives of decline around the local press whereby the critical perspective on the press is pessimistic. Hyperlocals are viewed as innovative, bottom-up, technology-led and a viable alternative to the institutionalized model of news production. A hyperlocal can be seen as a vehicle through which the socially conscious entrepreneur can extend the plurality and diversity of journalism while serving society (Harte et al., 2016). The study of Williams et al. (2014) found that hyperlocal news plays a valuable role in holding local power to account; however, two-thirds of entrepreneurs are paying for all costs of running their operations themselves.

The relationship between journalists and PR practitioners is described as a love-hate liaison with dissonance experienced by the journalists, but research indicates that those views may be shrinking (Shaw \& White, 2004). Despite concerns by journalists, communicators and PR practitioners are being encouraged to use media relations tactics to increase their presence in hyperlocal news. Hyperlocal news sites are significant elements of the contemporary media landscape and PR practitioners see a clear interest in targeting these sites. There are several reasons for this. As traditional local news become more remote from communities and independent local content is replaced by PR-based material, hyperlocal news is being produced by people in and of their communities. These news sites have a strong local angle and, besides reporting community events, they cover stories about local councils. Hyperlocal news audiences are exposed to a lot of information that could be high in civic value (Williams, Harte, \& Turner, 2015). These audiences are also potentially exposed to PR material that might be regarded by hyperlocal entrepreneurs as interesting for the community.

Content that is provided by PR practitioners has a greater chance of being visible on hyperlocal news sites, since they cover a small geographic area. Hyperlocals also provide some continuity of PR activities, publishing content from the same business or person more than once. PR advisers consider hyperlocals as the newest media relations opportunities for PR practitioners, teaching new rules for pitching hyperlocal news sites. These stakeholders make the point that hyperlocals need content and are ready to provide it: "With the right story, video or pitch, PR pros and their clients can easily score hyperlocal news coverage that will hit the web and circulate on social media sites (...)" ("Hot New Hyperlocal Media", 2011). PR practitioners have new options that specifically target hyperlocal sites' readers with locally oriented content: events, openings, promotions of restaurants, etc.

\section{Tendency of news PR-ization}

The crisis in journalism, caused by collapsing media business models and journalists' job losses, the continuing growth of PR worldwide, and the so-called 'democratization of media', which is providing avenues for media content production and distribution, are escalating the influence of PR (Macnamara, 2016). Research is beginning to explore how it might be changing media relations, with more exchanges taking place over digital platforms (Bajkiewicz, Kraus, \& Hong, 2011), and the content of PR material changing towards richer media content (Yoo \& Kim, 2013). 
Some researchers (Allern, 2002) argue that PR practitioners and other suppliers of pre-packaged news offer a subsidy to news organizations (through press releases, press conferences, video news releases, press briefings, lobbying and special reports). These subsidies assist news organizations with maintaining profitability by squaring the circle between cost cutting, while sustaining, if not increasing news output through greater pagination, more supplements and the development of online editions and other news services. Pressure on journalists to increase productivity via substantive growth in the pagination of national newspapers across the last two decades, achieved with relatively static numbers of journalists, have raised questions about the impact of these changing journalistic practices on the quality and independence of journalists' output (Lewis, Williams, \& Franklin, 2008b). The pressure has prompted desk-bound journalists to develop an increasing reliance on pre-packaged sources of news derived from the PR industry and news agencies (Lewis, Williams, \& Franklin, 2008a). The traditional news criteria may be supplemented with a set of 'commercial news criteria': the more journalistically a news source has prepared a story for publication, the greater the likelihood that it will become news, states Allern (2002) in his study. These processes have created new conditions for local journalism as well as public relations.

This connection between subsidies and journalists' willingness or need to use PR material can also be relevant in the case of hyperlocal news sites. Hyperlocal news sites may not have a wide impact, but they offer the brand the opportunity to connect with communities. PR practitioners mean that pitching hyperlocal reporters can be an easy, straight-ahead process. The picture of the hyperlocal news producer that is expressed by some voices from PR professionals is shifting towards the PR professional, who selects and packages a passive recipient of information rather than an active investigator. In the newsgathering and reporting processes, PR professionals and news agencies gain an increasing role in shaping the news content of media. Consequently, PR-generated stories are not only influencing journalists' newsgathering and reporting practices, but journalists are more likely to accept them without check or criticism (Lewis et al., 2008b). These processes lead to lesser editorial independence, since news is increasingly generated outside of news media organizations.

\section{Relationship between PR and journalism: A matter of trustworthiness}

Various researchers describe the interaction between journalists and PR practitioners as a field of tension (DeLorme \& Fedler, 2003), as paradoxical and uneasy one (Macnamara, 2014; Koch, 2016), featuring as it does mutual dependence and mutual distrust (White \& Hobsbawm, 2007) and often described as a lovehate relationship. On the one hand, as an instrument of PR, the practitioners communicate and advocate the particular interests; on the other hand, they resemble journalistic publications from which readers expect critical, unbiased, and objective reporting (Koch, 2016). The transactional information exchanges between PR practitioners and journalists are and have been central to news production. It is usually characterized as an 'interdependent' (Cornelissen, 2011) relationship or even a 'symbiosis' (Bentele \& Nothhaft, 2008). Even if the incorporation of media releases and other PR material into the news by journalists is not a new phenomenon, the apparent change is in the scale and regularity with which this is happening, as Jackson and Moloney (2016) point out. 
Traditionally, journalists have favoured a conflict model, based on assumption that the media are to function as watchdogs of economic and political interests. This conflict model has recently been recast as a 'trading' relationship in which journalists, working in under-resourced and under-staffed newsrooms, increasingly rely on PR sources for editorial copy in return for access to editorial columns for PR stories (Davis, 2008; White \& Hobsbawm, 2007). Everyday relationships between sources and journalists are much less adversarial than the latter suggests. Typically, the journalists and sources are 'inextricably linked', working in complementary (if not collusive) ways since each has professional ambitions, interests and needs which can be achieved most readily if they can win the cooperation of the other group (Blumler \& Gurevitch, 1981).

The picture painted by Lewis et al. (2008b) suggests that journalists are heavily reliant on pre-packaged information, either from the PR industry or other media. Some researchers are discussing 'PR-ization' of journalism - a phenomenon occurring within the news media, which is commonly described as 'churnalism' Davis 2008). Churnalism - the use of unchecked PR material in news - is viewed as an outcome of the broader process of structural and professional change. Within PR spheres, concerns about PR-ization have been evident for some years. The PR industry expresses concerns about the independence of much contemporary journalism (Jackson \& Moloney, 2016). For them, 'churnalism' erodes trust in journalism, because the message becomes weaker. Diminishing trustworthiness in journalism not only increases a tendency towards 'churnalism' but also becomes a ground for a new self-perceived role of PR practitioners as news players that serve the civil society. As the county council communicator expresses in the councils' information channel VGRfokus:

Running news production by ourselves is a way to deal with and handle an ever-faster media reality. Quite often pure inaccuracies are published and spread online, which highlights the need for an own news site where we can guarantee the correct facts. It is our responsibility as one of the institutions of a Swedish democracy (Lagersten, 2017).

The extensive production of PR subsidies and the reliance of the news media on such subsidies has resulted in a debate about the difference between 'news' as a PR activity and 'news' based on the principle of free access to sources and professional judgement of relevance and factuality by news organizations (Allern, 2015). A study by Firmstone and Coleman (2014) discusses how the growing professionalism of the PR industry makes journalists' jobs easier in terms of accessing information, but harder when trying to access the sources behind stories, due to the policy of the studied council to filter all communications.

Both mainstream and hyperlocal media tend to provide reduced coverage to a range of different voices (Radcliffe, 2015). The blurring roles of news providers between PR and journalism obstruct credibility for journalism, which affects both branches negatively. Allern (1997) means that marking distances from PR agencies is necessary for ethical and journalistic activities and for media credibility. Hyperlocal media can be considered as an institution that holds local elites to account through covering political issues and investigative reporting (Radcliffe, 2015), and with that in mind there is a need for deeper knowledge of how the hyperlocal media entrepreneurs' perception of their journalistic function aligns with the civic role, often ascribed to them. It is also important to discuss how these media entrepreneurs, working under financial pressure and having various professional backgrounds and aims with their sites, perceive and manage 
interactions and relationships with different stakeholders (e.g. local governments) that might have specific communication interests in the community.

The theoretical framework leads us further to these research questions:

RQ 1: How do local media entrepreneurs experience their role as news providers in the local society? RQ 2: How do local media entrepreneurs perceive their interaction with local governments and organizations?

RQ 3: How do local media entrepreneurs evaluate their interaction with local governments and organizations?

\section{Methods and material}

This study includes nineteen semi-structured in-depth qualitative interviews. The interviewees were selected from 75 digital hyperlocals identified in a systematic review (Jangdal, 2018) of a complete mapping of the Swedish media market - 587 regional and local media newsrooms (Leckner et al., 2017). All 75 hyperlocals have a news focus, a digital primary product, are locally based in the area that they cover, and that are independently owned and operated. As the industry is highly inconstant, the current total of hyperlocals may vary, when new start-ups are added and failing initiatives are shut down. As earlier research has recognized that most of the hyperlocals are digital, and digital maturity is strong in Sweden, this study will focus on digital hyperlocals only.

The interviewees were selected from online observations. The selection herein includes sixteen media entrepreneurs that operate digital hyperlocals, two communicators from municipalities where particularly interesting interactions occur with hyperlocals, and one representative from an organization directly involved with one of the media entrepreneurs and a local council. The interviews were transcribed and the interviewees were ensured anonymity. A selection of quotes is included in this article.

\section{The Swedish case}

Cultural and media-structural aspects are important for understanding how PR and journalism approach each other in a specific country. In order to understand the context of hyperlocal media operations, it is necessary to put a study into a specific cultural context, in this case Sweden.

Sweden is of particular interest as the transformations in the media landscape have been substantial in the country. Between 2004 and 2014, 100 local editorial offices in Sweden disappeared, which equals a third of all the local editorial offices in the country. During the same period, 25 per cent of the daily newspaper reporter jobs ceased to exist. Every fourth municipality in Sweden is now without a newsroom (Leckner \& Nygren, 2016).

Certain areas in Sweden have much less local media coverage compared to other European countries. The study Mapping the Road to Sustainability and Resilience, commissioned by Nesta (Cook et al., 2016), shows that some less populated areas in northern parts of Sweden completely lack local media coverage. In the 
most remote community, the distance between citizens and a journalist is $240 \mathrm{~km}$. Suburbs around large cities also have limited media coverage. They are hardly covered by metropolitan newspapers and rely mainly on free-sheets. Stand-alone sites are quite rare. The Nesta study notes that local authorities in Sweden have heavily expanded their public relations and information sector in the last five to ten years.

So far, there has been little research on interactions and relationships between local governments' PR activities and local journalism. However, in the wake of centralization and media void, independent hyperlocal initiatives in Sweden are breaking new ground. How they interact with local governments and organizations is both of national and international interest, as the changes in the journalism industry have been substantial in Sweden, and other countries may follow suit.

\section{Findings}

The empirical results from the in-depth interviews with hyperlocal media entrepreneurs and people representing municipalities and local organizations are presented in three parts. The first one represents the local media entrepreneurs' points of view concerning their role as news journalists in the local communities. In the second part, the media entrepreneurs' perceptions of interaction with local governments and organizations are presented. The third and last part concerns how the media entrepreneurs evaluate their interaction with local governments and organizations.

\section{Media entrepreneurs' experience of their role in the local community}

All of the entrepreneurial media initiatives in this study stem from strong community engagement. In the entrepreneurs' role as journalists, many of the interviewees see themselves as classic news reporters, concerned with elements of what journalism is supposed to comprise. Their goal is to perform qualitative journalism, bringing up current issues that involve the local population in the area they cover. Investigative journalism is often considered one of the crucial functions of local news. In comparison, in their study, Williams, Barnett, Harte and Townend (2014) express surprise that the number of hyperlocal initiatives that perform investigative journalism is so large, despite investigations are usually time consuming:

Investigative journalism is almost certainly declining in the mainstream local press because of its resource-intensive nature. It is as surprising as it is gratifying, then, to see that many community journalists in the United Kingdom are seeking to hold local elites to account (Williams, Barnett, Harte, \& Townend, 2014:17).

One of the interviewees claims that their superior motivation for starting a newspaper was the intention of producing qualitative news journalism, telling stories that otherwise would not be told. Hyperlocals analysed in this study act in places of media void, thus having no competing mainstream local media in their coverage area. Since local journalism is generally viewed in media research as a glue connecting local community by covering what's going on in the close neighbourhood, lack of locally oriented news has been expressed by 
media entrepreneurs as one of the driving forces for starting a hyperlocal media venture. Some journalists interviewed in the study, tell that their media initiative have started out with the goal of producing local news that would be of interest for the local population, such as monitoring of local council decisions, social issues and events. As one reporter says, she notices a gap of information to be filled:

The established paper tends to ignore (the community) and the surrounding area. They don't report about events from here, so obviously, people feel left out. Also, the local council feels overlooked not getting important information covered by the ordinary paper.

As a motivation for starting up news sites, some entrepreneurs mention dissatisfaction with the existing media monitoring. Monitoring of the local politics have traditionally been one of the primarily functions of mainstream media, and expressions like the one cited above, demonstrate media entrepreneurs connection to journalistic ideology and the perception of their role in the local community. Despite the results from Institute for media studies 2016/2017 (Truedson, 2017) that show slightly mainstream medias' increasing monitoring of local councils, we have to face that one of four Swedish municipalities lack a local editorial office (Truedson, 2017), which makes hyperlocal sites an important actor in the countryside where media void is mostly apparent. The hyperlocal reporters call for for more active journalism with higher local presence and relevance. For instance, one of the reporters has noticed that sometimes they update information more frequently than legacy media. Another one has observed that news coverage of the established local media leaves locally important information out, due to lack of the knowledge of the local community: 'There is a large information deficit as in many municipalities, which I think that we are trying to fill'.

Most of the studied hyperlocals do not offer space for debate on their sites because of experienced harsh debate climate created by anonymous writers that the individual reporter finds hard to control or respond to, or because citizens unwillingness to present their names in the public debate. Even if the hyperlocals can be seen as quite passive in creating a debate on the site, they can still function as an arena for community citizens and politicians by monitoring social issues such as education, care, business, etc. at the local level. An interviewee, managing her own hyperlocal site, stresses that she feels she contributes to the community, offering a forum for debate that the citizen cannot find anywhere else:

It's so useful that I find that some readers think I have to start my own party. They get more from me when I 'dissect' the elderly care than when they meet the local council. They say, 'We're lucky to have you,' and 'Push them' (...).

To be an arena for local debate is an object that several of the interviewed bring up as important. One reporter says that one ambition is 'to be the spokesperson to the local council'and states that he sees his role as local media entrepreneur and reporter as a protector of democracy in the two local councils he is covering. Reporting stories from and about local councils is a common activity of the hyperlocals, even in other countries. Researchers from Cardiff University and Birmingham City University show in their content 
analysis of United Kingdom hyperlocals that the most popular subject covered was local community activities, followed by stories about local councils (Williams, Barnett, Harte, \& Townend, 2014; Radcliffe, 2015).

Being a guardian of democracy is something that several participants in the study mention as essential in their work as local journalists, as for instance this reporter interviewed:

I want to stand free from influences from authorities and act as a defender of democracy in the local society.

Another interviewee, who has worked as a community reporter for mainstream media for several decades and now is hired as a reporter/communicator for one of the local councils' information channels, says the ability to cover local politics has diminished over time. There is no longer the same focus on applying the old journalism routines, scrutinizing what local politicians do and propose. Instead, the local coverage by traditional media has been reduced to quick reports with 'click bait', teasers/summaries that readers easily are tempted to click on. Her ambition in the community is to feed residents with important information so they can use their democratic rights and be updated on what is going on:

Being aware of local politics gives people a chance to influence. It's a democratic issue. Investigative reporting needs to be a part of that. People need to know when politicians do wrong, in order to not be passive consumers of news.

The communicators' expression shows a duality in role as a reporter who is concerned on democratic issues and as a representative for local council interests that potentially could be contradictive. Similar concern of unclear roles, changing practices and relations between council communicators and hyperlocal entrepreneurs is also analysed in relations with mainstream media. In Tenor's study (2017) of local councils perception of local journalism, some of council communicators describe their work as basically the same as what they have been doing as local journalists. Mainstream media tend to publish press releases without controlling them which at the first hand can be experienced as a credentials for the communicators' competence, but at the other hand perceived as unfulfilled expectations on news media as questioning and critical (Tenor, 2017: 78).

Self perception of the hyperlocal entrepreneur, regardless their closeness or distance to local councils as well as presence or absence of journalistic experience, is that most of them consider themselves being guardians of democracy and engaged representatives of the local community. To focus on the immediate community is important to every hyperlocal entrepreneur interviewed in this study. The editor of one independent hyperlocal is proud of their journalism having forced politicians to change their mind about important community issues:

The local government has several times tried to close down the senior high school, but our coverage has made a difference and contributed to the forming of citizens' groups. We still have our school! 
Some previous research (Franklin, 2014) presents an ongoing debate whether new entrepreneurial initiatives can be considered as journalism and who can be viewed as a journalist. But, as Barnett and Townend (2015:344) state, if hyperlocals contribute to local knowledge, to the accountability of local elites and to the ability of local people to lobby for changes, then they fulfil the journalistic norms for contributing to local democratic engagement, whether or not we call it 'journalism'. Labelling a hyperlocal entrepreneur as 'journalist' does not necessarily reflect the entrepreneur's publishing activities or the perception of professional roles. Hyperlocal news entrepreneurs make their own definitions of their roles and functions, in some cases removing themselves from being called journalists, as did one of the interviewed reporters:

Sometimes people get angry at what I've written. Those who are really angry call me a journalist. And I'm not a journalist; I do not consider myself a journalist but a writer and possibly a photographer.

The local media entrepreneurship faces both opportunities and challenges. One positive aspect of entrepreneurship is the freedom to do what they consider as hyperlocal journalism. After having worked at established papers and being told to keep up with the standpoints of the papers, they see themselves as free from partisan opinions. On the other hand, they are working under pressure to maintain their ambitions and to fill the space with relevant local news. The economic resources are small and they have to do most of the work by themselves: doing research, reporting, editing and distributing. Many of the entrepreneurs in this study express an economic vulnerability but at the same time point out that their main driving force is to serve the community as news providers. Despite lacking financial resources and time, many hyperlocals have an ambition to carry out local investigative journalism and perceive that they do it.

\section{The media entrepreneurs' perceptions of interaction with local governments and organizations}

A majority of the interviewees in this study have established interactions with the local governments in the municipalities in which they are located. Jackson and Moloney (2016) note that PR material in the news is not something new. The major change is in the scale and regularity in which this is happening. The study shows variations of interaction, spanning from outright partnerships, to being in regular contact with staff of the municipalities as sources for stories, to receiving press releases and writing about them and finally, to investigative reporting with no direct interaction with local governments.

One of the rural entrepreneurs in this study stems from a municipality initiative. A ski resort launched a project in the 1990's in order to increase citizen influence. A positive response from the community residents resulted in a subscription paper, which is still alive today. Other examples of outright partnership with governments and organizations are a couple of the national freelance co-ops. One of them has received start-up funding from Sweden's innovation agency Vinnova, which is a part of the Ministry of Enterprise and Innovation. In the other case, the local council was on board from the beginning, when the initiators behind the media company wanted to start its activity in 2016. The local council helped fund the start-up and also has a representative in a control group that discuss strategy decisions. As part of the same group, there is also an employee from Arbetarnas Bildningsförbund, ABF, which stands for the Workers' Educational 
Association, Sweden's largest adult liberal education association. The initiator behind the radio station sees no liability danger with the co-operations in place:

(...) I don't see any danger in establishing cooperation; the issue is rather how it is formed. For us it's absolutely necessary to have the local government involved, as our undertaking includes community participation and immigration integration.

The local council sees a big advantage in being directly involved:

We're a cofounder and co-applicant for grants. We see this project as a possibility to provide information to residents and people from other countries.

Journalism researchers and journalists consider that good journalism is characterized by distance to PRmaterial and other commercial and political interests. Collaborations between councils and local news providers are far more problematic as the interest groups would like to admit. It makes difficult for citizens to understand what kind of news are produced, on behalf to whom, who pays for the content and whether this kind of information can be considered as a reliable, credible news or a PR-material mascarading as news. News produced in collaboration or cooperation with local governments face similar criticism as sponsored journalism. A study (Andersson, 2017) of consumers' attitudes to semi-editorial content such as different forms of more or less hidden text advertising and sponsored journalism, show that citizens are critical to this kind of content and experienced sponsored news articles as problematic because the audience is fooled to believe that it is about editorial articles (Andersson, 2017:32). 'Symbiosis' (Bentele \& Nothhaft, 2008) between local councils and media entrepreneurs is noticed in several cases studied. Involvement of councils can be expressed in many ways and be more or less obvious. Being a part of media funding is one of the possible ways. It is common for the entrepreneurs in this study to have applied for grants, either for starting up or for special projects.

One entrepreneur in central Sweden received funding from the European Regional Development Fund, which grants money for innovation and research, the digital agenda and support for small and medium-sized enterprises. A grant from them allowed one media entrepreneur to hire a project leader and build up a necessary network. In addition, the local council has contracted the media entrepreneur to supply web-TV from municipal meetings; however, one of the founders of this particular media venture, would like the local councils to go much further than that:

Traditional media doesn't have the time and resources to report on everything. Meanwhile the local governments spend millions on their communication departments, cabling out information. Instead they could just as well fund an independent editorial office cover the municipality.

The PR industry is continuously employing ex-journalists (Moloney, Jackson, \& McQueen, 2013) for writing reports on behalf of the local council. In one countryside community of Sweden, the local council has hired a journalist with several decades of local community reporting experience, who took the initiative herself for 
the collaboration. A partnership was formed and the journalist was hired as a 'writer'. Development of diffuse roles of council communicators, even called "reporters" or "writers" is one of examples of how collaboration and partnerships between local councils and hyperlocal media entrepreneurs contribute to allusive, 'liquid' professional roles as Franklin and Carlson (2010) also notice. The development towards sliding concepts such as "semi-editorial" content, nivellating journalistic and communicators' work procedures as well as new kind of collaborations, seem to be driven by editors and advertisers simultaneously, Edström states in the report for Swedish Media Institute (Edström, 2017b).

\section{Evaluation of interaction between hyperlocals and local governments}

The interaction between hyperlocal media entrepreneurs and local government is a complex process, including both interrelated and contradictory goals of municipality as well as the entrepreneur. The local councils may have an aim to present their own information but are also keen to be visible in the independent, investigative news sites, since 'churnalism' is experienced as eroding trust in messages, as Jackson and Moloney (2016) state. The chief of a local council is pleased with the set-up, but is aware of a potential credibility issue:

However, there is a credibility risk with this arrangement. An internal writer cannot replace traditional media in that matter, but her (the hired writer, ed. remark) reporting is neutral. She has a journalistic background and a large level of integrity. We have received very positive feedback from the community.

Credibility is one of the issues that both local governments and media entrepreneurs are aware of and concerned about. Changing practices of PR mutually affect changing practices of journalism, which raises questions of whether independent journalism is possible at all. Especially is case of internal communicators writing on behalf to local councils, regional authorities or other political actors, the "neutral reporting" is difficult to obtain, regardless the individual communicators (or writers/reporters, as these terms are also used in description of employed information providers' tasks) ambitions to serve the community with information. The dependence relation between the employer and employee might influence what information and in which context is provided to the community members, what kind of issues are chosen for investigative reporting, what sources are used, etc., which is a matter for further research of this journalism-like communicators' information production.

One of the media entrepreneurs in most northern communities of the interviewees of this study stresses the importance of journalistic independence when having contacts with local councils:

We have to handle PR for the local council carefully. We have to nurse our credibility. We don't have the same clear boundaries as traditional media, although they have connections too, that the general public is not aware of. 
Similarly to mainstream journalism, the hyperlocals consider credibility a corner stone of their existence on media market. As a consequence of unclear collaborations and uprising alternative media channels, the publics face difficulties to determine what is true or false, who is the sender and for what purpose the news article is written. Credibility of the hyperlocal venture is closely connected with nearness to the local community, visibility and participation in community's daily life as well as transparency in relations to the local politics and businesses.

Journalists of mainstream media are, as Davies (2008) notices, increasingly desk-bound and less able to give attention to the crucial practices of fact-checking and independent navigation. Hyperlocal media entrepreneurs are not as desk-bound, as they work locally and usually have good contact with and knowledge of the local community, which can also include the local council:

I have direct contact with the municipal council. And we speak on the phone on a regular basis. There are good contacts. They often use me (...); they call if they want to get something out.

Local media entrepreneurs have knowledge of the local community that is hardly available for the deskbound journalists of the increasingly centralized regional media. It allows media entrepreneurs to establish closer contacts with municipalities and monitor their activities and decisions. As the entrepreneur from one hyperlocal expresses:

I have access to it simply because I'm closer to reality than the reporters who travel here from Helsingborg or Malmö. They only take what is told in the press releases and publish it.

Although the hyperlocals are not desk-bound and participate in community's daily life, there is no guarantee that facts from local authorities will be checked up. The hyperlocal entrepreneur might perceive that the contacts with the authority members are well established; the individual entrepreneurs' knowledge of journalistic work may be lacking or the entrepreneur might believe he/she is just doing a good job for community members spreading information from the local authorities. Even if there is time available for fact-checking, it may be considered unnecessary since the source is experienced as credible.

To sum up, spreading PR material from local councils' home pages or publishing information that has been conducted from direct interaction with the local politicians can have various reasons and meet different goals for the media entrepreneur. Municipality information can function as a complement when the entrepreneur has no time to write other articles, as the news site has to keep a fair amount of activity to attract readers. Since local governments have low visibility in regional news (Paek, Yoon, \& Shah, 2005), even re-posted information from municipalities' home pages can serve the residents with a contextualized picture of what happens in the local community, although the news value of such reposts can be questioned.

Another reason why information from municipalities takes place in the local news site is how the entrepreneur understands his or her contribution to the democratic processes in the local community, as the citation of a hyperlocal site illustrates: 
I think it's important to help and spread (information). Local councils' politics receive so many complaints today, but the basis for democracy lies in it.

Several media entrepreneurs have a strongly expressed position as a watchdog that monitors municipal policy and keeps residents informed. The entrepreneur may view the hyperlocal news site as a powerful institution that has ability to influence local politics, and the perceived influence may stimulate further interaction between local government and media entrepreneur. Despite that, other findings in this study and some previous research show a limited role of the hyperlocals to act as a watchdog of democracy, due their divergent perception of the hyperlocals role in reporting and in interacting with other stakeholders, but also due the scant financial and staff resources.

\section{Conclusions}

Findings show that the hyperlocal media entrepreneurs' role as journalists can take different shapes and be perceived in various ways. The entrepreneurs may view themselves as traditional news reporters. Their goal can be to perform high-quality journalism, monitor local politics and local events, as well as giving voice to the community residents. Among the descriptions of the media entrepreneurs' roles we can also find some distancing from the traditional perception of a reporter, as the entrepreneurs regard themselves as 'writers' rather than journalists. This view is represented by both media entrepreneurs who are contracted by municipal councils and those who interact with the local authorities less regularly and on a free basis.

The main ambition by the hyperlocal media entrepreneurs in this study is to act as professional media actors who promote conversation among the community residents, local governments and organizations. The media void is considered a main motivation by several of the hyperlocal news initiatives. The media entrepreneurs view their news sites and papers as an important part of the local community, filling the media void when the regional papers do not cover the local news or do it sporadically and incompletely, for example, primarily reporting crimes. The hyperlocal news sites, according to the media entrepreneurs, provide a conversation and information room for local governments and organizations, as well as a channel of local events that are relevant for the community.

We have noticed that the media entrepreneurs stress their role as guardians of democracy, but there is a variety of ways this role gains expression. Both having tight interaction with local governments and, in other cases, not having any direct contact with local councils, can be seen as an act of democracy protection. Strong interrelationship with local councils can mean that the media entrepreneurs' knowledge of local politics enables the entrepreneurs to apply some pressure on political decisions - at the other hand, strong ties between the hyperlocal news site and local authorities may be considered as threat for journalistic credibility and for democratic function of news media. The ability to act as a watchdog depends on the relationship the local governments and media entrepreneurs have. Media entrepreneurs contracted by the local councils as their spokesmen have likely other conditions for investigative reporting than the entrepreneurs whose contact with local councils involves questioning. The other view presented by the media entrepreneurs is that investigative journalism is only possible when the reporters have no direct interaction with the local governments. 
The influence of organizations' communication departments' media content is continuously growing through new media practices, as Macnamara (2016) states. Local councils are developing new communication strategies at the same time as media organizations experience financial struggles with staff cuts and closures as a consequence. Communication departments in some councils are built up with a budget and staff that are comparable to an entire newspaper office. Professional roles are blurring as it becomes common for journalists to be recruited as communicators, and 'change side' from reviewing information to distributing information. Communication departments use journalistic methods and speak of themselves as editorial offices rather than communication departments, as we have seen in the case of county council VGR (Lagersten, 2017). Diffuse collaborations, elusive professional roles including use of established concepts in other communication contexts (it is a matter of discussion who is "reporter", "editorial office" and what is considered to be "news") might contribute to lower credibility for hyperlocal news - and in some ways for the local authorities.

The role of hyperlocal media entrepreneur in interaction with local councils can be described as diverse: the interaction varies in scale from no direct communication to an intense interaction. The interaction may be initiated mainly by the local politicians or by the media entrepreneurs, usually in different situations or for different purposes.

We observe various levels/modes of interaction, as follows:

- No direct communication/personal interaction. The entrepreneurs want to be as independent as possible when monitoring the local governments without interaction and prefer to use available information about the decisions and work processes of the local council.

- Regular interaction - the council/local politicians are the driving force. In this case, the entrepreneurs have a direct contact with the local council. The media entrepreneurs' goal is to help the council to spread information.

- Sporadic interaction. The council is initiating interaction in order to make the 'good news'. Some media entrepreneurs experience that the local politicians seek contact with the entrepreneurs with the intention to inform about events/decisions that sets the local council into a positive context.

- Interaction on regular basis - critical voice. In this case, the media entrepreneurs are seeking contact with the council, with intention to question their decisions or getting information about a specific event/decision.

The hyperlocal media entrepreneurs can partly fill the existing media void by acting as an arena for local conversation; although most of them are economically vulnerable and have different ambitions with their news sites. More or less visible involvement of municipalities and organizations likely has an impact on what kind of news and how they are reported, depending on the media entrepreneurs' perception of their relationship with the different stakeholders and on the perceived role as a professional media entrepreneur - and also on how they understand qualitative local journalism. Conclusively, the findings of the study show that there is a diversity of the perceived roles of the hyperlocal entrepreneurs with an emphasis on watchdog functions and societal motives for establishment of the news sites. Also, the interactions with the local 
councils vary, as well as the hyperlocal entrepreneurs' evaluation of how the information provided by the councils can or should be handled.

The findings suggest two priorities for future research. Hyperlocals are usually considered to fulfil, at least partly, a democratic and civic function in the society by carrying out investigative journalism and thus acting as watchdogs in the local community. However, much of the hyperlocals' impact on the community is unmeasured, as is the quality of the hyperlocal news content. An investigation of hyperlocal news sites' quality and the news entrepreneurs' perception of it is needed, as is the public's (local inhabitants, local governments and other organizations) perception of hyperlocal news quality. Moreover, this study presents a sustainability challenge for the hyperlocal news entrepreneurs. Many of the hyperlocal news owners and reporters can be considered 'lifestyle entrepreneurs', driven primarily by their interest in serving community needs rather than making a profit. As the hyperlocal media entrepreneurs usually consist of one-person editorials and typically lack time, financial and professional support, they are vulnerable. Thus, strategies for the sector to become more sustainable are required.

\section{References}

Allern, S. (1997). Når kildene byr opp til dans: Et søkelys på profesjonelle kildeorganisasjoners mediestrategier og nyhetsinnflytelse. PhD thesis. Oslo: University of Oslo.

Allern, S. (2002). Journalistic and commercial news values: News organisations as patrons of an institution and market actors. Nordicom Review, 23(1-2), 137152. http://www.nordicom.gu.se/sites/default/files/kapitel-pdf/42 137-152.pdf

Allern, S. (2015). PR-byråene og politikken. In Allern, S. Ihlen, O. \& Skogerbo, E. (eds.), Makt, medier og politikk: Norsk politisk kommunikasjon, 118-131. Oslo: Universitetsförlaget.

Andersson, U. (2017). Saklig och trovärdig men partisk - synen på sponsrad journalistik. In Truedson (ed.), Näjtiv, Kånntänt, brändidd - Ska textreklam bli räddningen för journalistiken? Stockholm: Institutet för mediestudier.

Bajkiewicz, T. E., Kraus, J. J., \& Hong, S. Y. (2011). The impact of newsroom changes and the rise of social media on the practice of media relations. Public Relations Review, 37(3), 329-331. https://doi.org/10.1016/j.pubrev.2011.05.001

Barnett, S. (2009). Journalism, Democracy and the Public Interest: Rethinking Media Pluralism for the Digital Age. Working paper. Oxford: Reuters Institute for the Study of Journalism. https://reutersinstitute.politics.ox.ac.uk/sites/default/files/201711/Journalism\%20Democracy\%20\%26\%20Public\%20Interest.pdf

Barnett, S., \& Townend, J. (2015). Plurality, policy and the local. Journalism Practice, 9(3), 332-349. doi: 10.1080/17512786.2014.943930

Bentele, G., \& Nothhaft, H. (2008). The intereffication model: Theoretical discussions and empirical research, in A. Zerfass, B. Van Ruler, \& K. Sriramesh (eds.). Public Relations Research: European and International Perspectives and Innovations, 33-48, Wiesbaden, Germany: VS Verlag fur Sozialwissenschaften. 
Blumler, J., \& Gurevich, M. (1981). Journalists' Orientations to Political Institutions: The Case of Parliamentary Broadcasting, in P. Golding, G. Murdock and P. Schlesinger (eds.). Communicating Politics: Mass Communications and the Political Process, 67-92. Leicester: Leicester University Press.

Carson, A., Muller, D., Martin, J. \& Simons, M. (2016). A new symbiosis? Opportunities and challenges to hyperlocal journalism in the digital age. Media International Australia, 161(1), 132-146. doi:10.1177/1329878X16648390

Cook, C., Geels, K. \& Bakker, P. (2016). Hyperlocal Revenues in the UK and Europe: Mapping the Road to Sustainability and Resilience. London: https://www.nesta.org.uk/sites/default/files/hyperlocal-revenues-in-the-uk-and-europe-report.pdf

Cornelissen, J. M. (2011). Corporate Communications: A Guide to Theory and Practice. London: Sage.

Davis, A. (2008). Public Relations in the News. In B. Franklin (ed.), Pulling Newspapers Apart. 256-64. Abingdon: Routledge

DeLorme, D., \& Fedler, F. (2003). Journalists' hostility toward public relations: An historical analysis. Public Relations Review, 29, 99-124. doi:10.1016/SO363-8111(03)00019-5

Edström, M. (2017). Trovärdighet till salu? Etiska dilemman när reklam och journalistic blandas samman. In Truedson (ed.), Näjtiv, Kånntänt, brändidd - Ska textreklam bli räddningen för journalistiken? Stockholm: Institutet för mediestudier.

Firmstone, J., \& Coleman, S. (2014). The changing role of the local news media in enabling citizens to engage in local democracies, Journalism Practice, 8(5), 596-606. doi:10.1080/17512786.2014.895516

Hot New Hyperlocal Media: How PR Can Pitch and Place Stories in These Explosive New Outlets. (2011, June 14). Retrieved from http://www.marketwired.com/press-release/hot-new-hyperlocal-mediahow-pr-can-pitch-place-stories-these-explosive-new-outlets-1526817.htm

Franklin, B. A., \& Carlson, M. (2010). Introduction. In B. A. Franklin and M. Carlson (eds.) Journalists, Sources and Credibility: New Perspectives, 1-18. . London: Routledge.

Franklin, B. (2014). The future of journalism. Digital Journalism 2(3), 254-272. doi:10.1080/1461670X.2012.712301

Harte, D., Williams A. \& Turner, J. (2017). Reciprocity and The Hyperlocal Journalist. Journalism Practice, 11(2-3), 160-176. doi:10.1080/17512786.2016.1219963

Holt, K. \& von Krogh, T. (2010). The citizen as media critic in periods of media change. Observatorio (OBS*), 4(4), 287-306.

Jackson, D. \& Moloney, K. (2016). Inside churnalism. Journalism Studies, 17(6), 763-780. doi:10.1080/1461670X.2015.1017597

Jangdal, L. (in press, 2019). Local democracy and the media: Can hyperlocals fill the gap? Nordicom Review. Harte, D., Turner, J., \& Williams, A. (2016). Discourses of enterprise in hyperlocal community news in the UK. Journalism Practice, 10(2), 233-250. doi:10.1080/17512786.2015.1123109

Karlsson, M., \& Holt, K. (2014). Is anyone out there? Assessing Swedish citizen-generated community journalism. Journalism Practice, 8(2), 164-180. doi:10.1080/17512786.2013.859830

Koch, T. (2016). Journalism or public relations? A quantitative survey of custom publishing editors in Germany, Public Relations Review, 42, 345-352. https://doi.org/10.1016/j.pubrev.2016.01.003 
Kurpius, D., Metzgar, E., \& Rowley, K. (2010). Sustaining hyperlocal media: In search of funding models. Journalism Studies, 11(3), 359-376. doi:10.1080/14616700903429787

Lagersten, E. (2017). Därför drar VGR igång egen nyhetssajt. Retrieved 2018-03-19 from https://vgrfokus.se/2017/11/ledare-darfor-drar-vgr-igang-egen-nyhetssajt

Leckner, S., \& Nygren, G. (2016). Det lokala och hyperlokala medielandskapet: nyhetspublicering utanför de etablerade medierna, pp. 42-85. In Truedson, L. (ed.) Mediestudiers årsbok 2015/2016: tillståndet för journalistiken. Stockholm: Institutet för mediestudier.

Leckner, S., Tenor, C. \& Nygren, G. (2017). What About the Hyperlocals? The drivers, organization and economy of independent news media in Sweden. Journalism Practice, 1-22. doi: $10.1080 / 17512786.2017 .1392254$

Lewis, J., Williams, A., \& Franklin, B. (2008a). Four rumours and an explanation. Journalism Practice, 2(1), 27-45. doi:10.1080/17512780701768493

Lewis, J., Williams, A., \& Franklin, B. (2008b). A compromised fourth estate? Journalism Studies, 9(1), 120. doi:10.1080/14616700701767974

Macnamara, J. (2014). Journalism-PR relations revisited: The good news, the bad news and insights into tomorrow's news. Public Relations Review, 40, 739-750. https://doi.org/10.1016/j.pubrev.2014.07.002

Macnamara, J. (2016). The continuing convergence of journalism and PR: New insights for ethical practice from three-country study of senior practitioners. Journalism and Mass Communication Quarterly, 93(1), 118-141. doi:10.1177/1077699015605803

Moloney, K., Jackson, D., \& McQueen, D. (2013). News journalism and public relations: A dangerous relationship. In S. Allan and K. Fowler-Watt (eds.) Journalism: New Challenges. Poole, England: CJCR: Centre for Journalism \& Communication Research, Bournemouth University, 259-281.

Nygren, Gunnar; Leckner, Sara \& Tenor, Carina (2017). Hyperlocals and Legacy Media: Media Ecologies in Transition. Gothenburg: Nordicom Review.

Paek, H-J., Yoon, S-H., \& Shah, D. (2005). Local news, social integration, and community participation: Hierarchical linear modelling of contextual and cross-level effects. Journalism and Mass Communication Quarterly, 82(3), 587-606. https://doi.org/10.1016/j.pubrev.2014.07.002

Pickard, V., \& Stearns, J. (2011). New models emerge for community press. News Paper Research Journal, 32(1), 46-62. doi:10.1177/07395329110320015

Radcliffe, D. (2012). Here and Now - UK hyperlocal media today. London: Nesta. https://media.nesta.org.uk/documents/here and now uk hyperlocal media today.pdf

Radcliffe, D. (2015). Where are We Now? UK Hyperlocal Media and Community Journalism in 2015. Centre for Community Journalism at Cardiff University 2015, 1-36. https://papers.ssrn.com/sol3/papers.cfm?abstract id=3045571

Shaw T., \& White, C. (2004). Public relations and journalism educators' perceptions of media relations. Public Relations Review, 30, 493-502. https://doi.org/10.1016/j.pubrev.2004.08.004

Tenor, C. (2017) Kommunerna om tillståndet för den lokala journalistiken. In Truedson (ed.) Mediestudiers årsbok - tillståndet för journalistiken 2016/2017. Stockholm: Institutet för mediestudier 
Truedson, L. (2017) Kommunbevakningen har ökat - trots fortsatt ekonomisk press. In Truedson L. (ed.) Mediestudiers årsbok - tillståndet för journalistiken 2016/2017. Stockholm: Institutet för mediestudier

Wadbring, I., \& Ödmark, S. (2016). Going Viral: News Sharing and Shared News in Social Media. Observatorio (OBS*), 10(4), 132-149. http://dx.doi.org/10.15847/obsOBS1042016936

White, J., \& Hobsbawm, J. (2007). Public relations and journalism. Journalism Practice, 1(2), 283-92. doi:10.1080/17512780701275606

Williams, A., Barnett, S., Harte, D., \& Townend, J. (2014). The State of Hyperlocal Community News in the UK: Findings from a survey of practitioners. Cardiff university, https://www.communityjournalism.co.uk/wp-content/uploads/2014/07/Hyperlocal-CommunityNews-in-the-UK-Final-Final.pdf

Williams, A., Harte, D., \& Turner, J. (2015). The Value of UK Hyperlocal Community News. Digital Journalism, 3(5), 680-703. doi:10.1080/21670811.2014.965932

Yoo, K-H., \& Kim, J. R. (2013). How U.S. state tourism offices use online newsrooms and social media in media relations. Public Relations Review, 39(5), 534-541. https://doi.org/10.1016/j.pubrev.2013.08.005 